\title{
Hermeneutics of Journalistic Creative Work
}

\author{
Igor Nicolaevich Blokhin ${ }^{1}$ \\ Sergey Nicolaevich Ilchenko²

\begin{abstract}
1 Department of Theory of Journalism and Mass Communication, Saint Petersburg State University, St. Petersburg, Russia
2 Department of TV and Radio Journalism, Saint Petersburg State University, St. Petersburg, Russia
\end{abstract} \\ Email: igor.blohin@mail.ru
}

\section{Doi:10.5901/mjss.2015.v6n4s4p49}

\section{Abstract}

The article deals with understanding the person in the journalistic creative work methodology. The textual nature of social action is proved. Notional restrictions of understanding in journalism and functional peculiarities of journalism in the hermeneutics context are revealed. The forms of hermeneutics research in the journalistic search, the author's philosophical hermeneutics and creative hermeneutics from the point of view of the compositional structure of a work are suggested as fundamentals of journalism hermeneutics. The implementation of mass communication effect model is suggested for the transition from understanding the person to understanding the social processes. The communication consequences and social actions in social life are regarded as the effect. The correlations with other people's actions suggest both understanding the sense of these actions and communication (including the indirect one) among the carriers of such senses. At the individual level the social action as the communicative effect manifests itself as a social role - a standard response corresponding to the acting person's status. The identity as experience of belonging to a certain group is formed on the status basis. At the group level the identities demonstrate integral effects which are the results of different varieties of communities' communicative compatibility. Methodical solution of the problem of understanding consists in the time and attention structure analysis. Understanding as the purpose and the result of journalistic activity presupposes including explanation and interpretation into the complex of journalistic functions. A separate line of research of understanding problem in journalism and mass communication is acquisition of motivation complex of the author's success which should be understood as the essential feature of mass media efficiency. The structure, form and efficiency of journalistic work depend upon both objective factors of socio-political medium of mass media functioning, information production technology and the author's subjective choice of fundamentals of activity conditions, attitude to his role behavior at the stage of information collection and work publishing targets. Fundamentals include reflective, standard, pragmatic and emotional conditions.

Keywords: understanding, actuality, reality, journalism, communication efficiency, identification, hermeneutics

\section{Introduction}

The core object of understanding in the communication processes appears the person who is manifested directly in the social action and indirectly in the text (or as the text). "The action, which due to the sense assumed by the acting person (or acting persons) is associated with other people's action and is geared to it, is termed social" (Veber, 1990). The main sign of social action is the subjective sense. The person's understanding is achieved through the comprehension of senses which he/she is guided by.

In order to understand the text it should have a sense, understanding the text means understanding the author's intention, the motives of the characters' actions and emotions, the reader's feelings who takes into consideration the appreciation based on the principles and norms existing in his/her social and cultural environment. The problem of text understanding is defined by Aristotle: "...every word must be understandable and mean something; and not many things but one; in case it has several meanings, it is necessary to explain in which of them it is used" (Aristotle, 1976). The speech act, as it is understood by medieval scholastics, presupposes the language convention (commonality of the communication language) and the speech convention (the usage of words in their proper meanings, clear to the interlocutors from the conversation context) (Shmonin, 2012).

\section{Literature Review}

Understanding a text is possible only providing the reconstruction of concepts meaning ("cognition in concepts" (Hegel, 
1977)), ideas ("understanding is self-understanding in a way" (Gadamer, 1988)) and the context ("to understand an object is to make clear its connections to other objects" (Kazennov (2015)). The logical process of understanding includes explanation, digestion (consent ("agreement") with the established meanings of concepts, ideas and context) and interpretation. Derrida states that the text excludes the meaning because of plurality of interpretations (Derrida (2000). In this sense understanding acquires the qualities of the communicative effect: the text will be effective if the recipient educes the author's intention without distortions and additions.

The utterance appears as a form of the thought-to-word (sign) motion that has the consequence in the form of difference between the actuality and reality. The actuality is the collection of facts (including social actions), record of which is the information. The reality is the actuality image existing in the human being's mind or its group forms (mass, social, national consciousness). The reality is the product of perception of the actuality. The real is formed by filtering the actual through the lens of values, world outlook and mentality. To understand a person means to understand his/her reality.

The contradiction of factual and real is expressed in the protest against the actuality and its justification. The protest sources were determined by Kant (the experience of ethic recognition (Kant, 1994), Hegel (the experience of coercion (Hegel, 1990)), Heidegger (being-towards-death (Heidegger, 1997)), Zinovyev (intelligent factor (Zinovyev (2006)).

The requirement of the text understanding is the meaning expressed in perception by the recipient and having the subjective assessment. The essence of the text understanding is the recipient's auto communication, the result of which is identification as the achievement of his/her identity with the text (i.e. with the interlocutor). Thus, according to Bakhtin's interpretation, the character understanding is achieved by the way of "empathy": I have to go through - to see and to learn - what he/she is going through, drop into his/her place, as if to coincide with him/her" (Bakhtin, 2003)).

The identification process should also be considered as a way of adopting a social role in respect of the message and the condition of emergence of interest in the work. The identity of the text and the person is determined by their common sign-oriented nature: the person's being "is locked" by symbols - status, social action (including media behavior (Blokhin, 2012,), writing and speech, the external attributes and plasticity.

The stadiality of understanding as the process - explanation, mastering and interpretation - is determined by the personality integration (Mid, 1994) with a focus on the components me, I and self. "Me" is reflexive and socially regulated, it is based on expectations of other people and "the generalized other". It requires an explanation as the rational justification of social action. The role of media in shaping the image of "the generalized other" is expressed in particular with the phenomenon of "the spiral of silence" (Noelle-Neumann, 1996). Rationalization of explanation is related to the necessity of its "speaking through", external "interpretation" of a person takes into account, above all, its social statuses. The compliance of the role with the status at the stage of explanation is meant as an axiom of social action.

The impulsive "I" is expressed in the creative adoption of concepts, ideas and the context. At this stage, "interpretation" of a person is expressed in identification, social game (Gofman, 2000). The procedure of understanding, including assessment and "empathy", is also manifested in the phenomenon of "language play" (Wittgenshtein, 1994).

"Self" as a complex of the impulsive and the reflexive is manifested in the ability to evaluate and design social activities. The play is carried out at the level of interpretations, creative comprehension of human actions, behavior and activities. It is backed up by understanding the nature, the analysis of the events, the logic of relations. Without this "the play" is more like a hysterical fit, because there is no sense of its own accord, its appearance depends directly on those impressions, events, interests by which the person lives in the present. The processing of these impressions, events and interests is the function of thought" (Sarabyan, 2011).

\section{Method}

\subsection{General methodology}

Thus, methodical understanding of a person involves the selection of both external rational status indicators, and internal identifying characteristics of the personality. In the media sphere outside regulation by the information generators and communication regulators is manifested by segmenting target audiences on the basis of social characteristics. The external analysis is represented with explanatory models of correlation of an individual's statuses and his/her social actions in the journalistic works. The "external" social statuses and roles are represented in Table 1. 
Table 1. Social indicators ("external")

\begin{tabular}{|l|l|}
\hline Socio-demographic & $\begin{array}{l}\text { sex, gender, age, citizenship, place of residence, type of settlement, nationality, language, family members } \\
\text { and family living cycle }\end{array}$ \\
\hline Socio-professional & profession, occupation, professional status, enterprise type \\
\hline Sociocultural & Education religion, subcultural and countercultural peculiarities, recreational practices \\
\hline Political & voters, party and social movement members, activists, staff \\
\hline Consumptive & Income consumption activity, brand loyalty, degree of utilization of goods, consumption experience \\
\hline
\end{tabular}

The external indicators also include stable psychological features of an individual, represented in Table 2.

Table 2. Psychological indicators ("external")

\begin{tabular}{|l|l|}
\hline Socio-psychological & picnic: rapport and adaptability, athletic: communicability and expressiveness, asthenic: restraint and caution \\
\hline Type of thinking & imaginative, logical, mixed \\
\hline Temperament & choleric, sanguinic, phlegmatic, melancholic \\
\hline Orientation & introvert, extrovert, ambivert \\
\hline
\end{tabular}

The internal identifying features are mobile, connected with interests, aspirations, inclinations, ideals. They include values, value orientations, and worldview principles (Table 3).

Table 3. Internal identifying features

\begin{tabular}{|l|l|}
\hline Ideological & $\begin{array}{l}\text { conservatives, liberals, communists, social democrats, nationalists; } \\
\text { left-wingers, centrists, right-wingers }\end{array}$ \\
\hline Productive and Consumptive & Innovators early followers, early majority, late majority, underachievers \\
\hline Type of Instinct Domination & $\begin{array}{l}\text { egophiliac (self-preservation), genophiliac (procreation), altruistic (mutual help) } \\
\text { explorative (curiosity) } \\
\text { dominant (leadership) } \\
\text { love of liberty (freedom), } \\
\text { caring for dignity (retaining dignity) ... }\end{array}$ \\
\hline Type of Identification in the Communication & function, character, image, author \\
\hline Type of Media Behavior & потребитель, communicator, author, navigator \\
\hline \multicolumn{1}{c}{...} & \multicolumn{1}{|c}{... } \\
\hline
\end{tabular}

Table 3 is open to be filled, as the researcher, representing focusing on specialized fields of knowledge, can offer his/her own grounds to highlight the characteristics of the individual. The creation of such "matrix" typologies is possible with regard to the analysis, such as speech characteristics (Torsueva, 1976), sign and symbol attributes (Lich, 2001) or the language of gestures and facial expressions (Piz, 2006).

\subsection{Typical examples}

The ways of understanding a person suggested by the authors range from explanation to interpretation. Let us consider publications that demonstrate different points of view in the coverage of the crash of Germanwings aircraft in the French Alps on March 24, 2015.

Example 1. In Anna Roze's article "The Crash Could Have been Avoided" in the "Rossiyskaya Gazeta" the author technologically follows the facts, documentary and expert evidence, uses the information of the press. The reasons for the disaster are clear; the pilot's behavior could have been rationalized. The following sources are used: 1) the prosecutor's office statement, 2) investigators' evidence, 3) the statement of the airline representative, 4) the statement of a representative from the University Hospital in Düsseldorf, 5) the pilot's girlfriend's message of Andreas Lubitz's dissatisfaction with working conditions, 6) biographical information, 7) posts from the German press ("Welt am Sonntag", "Bild am Sonntag", "Bild") (Roze, 2015).

Example 2: In an interview with a German journalist Christoph Hörstel on Klagemauer TV the attention is focused on the actual contradictions that are ignored in the course of the investigation due to the dominance of the version of the pilot's mental illness. The problem is accounted for the presence of professional barriers to information access, blocking 
it: "the journalism, the assessment of the facts becomes impossible; if only to work with dubious assertions ... Journalism as such no longer exists ... This time contradictory statements are not dealt with ... there is no confidence in it.

Example 3. Eduard Limonov also draws attention to the contradictions, offering conspiracy version of the event: "How marvelously, brilliantly quickly they found epy guilty in the crash of Germanwings plane, a copilot, an honest smiling German guy of, say, 28 years, dead! and made him a gloomy ominous mass suicide - a criminal, on the basis of several sounds in a black box! Already searches are being executed, making haste, hurry! To quickly hide behind days and hours and waste news, the real cause of the crash, most likely it was a test of laser weapons of the United States". The reasons of what happened are clear to the author, but he does not trust the official version. He does not trust, just because of his interpretation of the pilot's image - "a fair smiling German guy" - does not correspond to the proposed version of the crash.

Example 4. Alexander Prokhanov denies the very possibility of understanding the causes of the crash: "This murder does not find any explanation, it generates a lot of versions the most original of which are associated with psychiatry of an individual character ...". The abundance of information, thus, is an obstacle to understanding. For the author in his interpretation of events the context is the main thing: "a particular German, being a part of this nation, is able to commit such acts of suicide... The Germans ... are monstrously raped and repeatedly exhausted ... The Germans were negated, the Germans were banned to feel themselves as a great Gothic nation, aiming to the heaven. And every step of a today's German, every step of today's German society is controlled and subjected to truncation, enormous pressure. And this causes a deep depression in people... the act of suicide does not mean that it is an act of suffering and a desire to break with life. Maybe this act should be interpreted as an act of rebellion. Maybe a German or Germany, who are in a terrible humiliation, try to break out of control, they have resorted to the last resort - to the death, which saves a man from this controlling" (Prokhanov, 2015). For Prokhanov the revealed context of the event is only a pretext for philosophical and publicist interpretation.

\section{Results}

\subsection{Hermeneutics of journalism}

According to Heidegger, existence within the lifetime is never "whole" and "complete", death is not implemented in it as its main feature. But to achieve the end in order to realize one's "being-toward- death" is not necessary: the reason of the impossibility of being lies not in the imperfection of cognition, "a hindrance arises from being of things in being" (Heidegger, 1997). Being of human essence has the matrix nature; a man is accustomed to understand himself and others as the text.

In journalism mutual understanding can be achieved, even if the problems in some text are not mentioned. The integral coverage of the event and the ability of the recipient to the integrated organization of information really matters, i.e. understanding is achieved as a result not of relevant explanation but of the existing model of perception. Understanding, thus, is set not only on the basis of the uttered but also on the basis of the unuttered. Understanding is set not due to the stringency of concepts, but also due to the mutual agreement with their meaning. The expectation of an appropriate recipient's response is implicated in understanding.

Defined ideas can be regarded as grounds for journalism hermeneutics as scientific hermeneutics of journalism search (example 2), as the author's philosophical hermeneutics (example 4), as a creative hermeneutics at the level of the compositional structure of the work (example 1). The author conveys his/her understanding of the world through the accentual features of the reality that he/she arranges in the work (examples 1 and 3) through the symbolic conception (example 4), not only through specific material attributes, but also the work itself and his news media as a symbol. Vision of the world - this is both a story about what is happening "inside" of the text (example 1), and the story of the larger reality, which extends beyond its scope and which includes both the author and the recipient (examples 2, 3 and 4).

This reality is told about not directly, but in a way that the recipient understands everything perfectly well (example 2) and indirect conveyance of meaning is symbolic by definition. "We are more accustomed to understand the symbol as something more specific, however symbolic specifics, and even more allegorical specifics are only a special case of symbolism, which in general terms reduces itself to the principle of indirect conveyance of meaning" (Salynskiy, 2009).

\subsection{Model of understanding in mass communication}

Based on the statements considered we offer a dynamic model of understanding as the process of social media communication. The world around us is represented by two areas (which can be defined as the fields, in this case it does 
not matter) - the sphere of reality and the world of actuality. Let us clarify the statements proposed in the Introduction to the article. The actuality is formed as a collection of facts, details of which are the information. Social activities are also included into the group of facts and fill the sphere of actuality. The sphere of reality is the image of actuality existing in the mind of the individual or in the public consciousness. The reality is, in part, a product of feelings from actuality. The real is formed by filtering actuality through the prism of values, outlook and mentality. Together, both areas give a new quality to the information - knowledge.

Journalism functions at the same time in the designated areas: the collection (sampling) of information on facts as events of actuality combined with its image (reality) by way of explanation, attitude to understanding and interpretation. Journalists and editorial staff give the message (work) the corresponding content and form (genre).

Message recipient as a full participant in the communication process selects (chooses) the information and knowledge (in particular in the form of "agendas" and "world views") offered to him. The decisive factor for recipients in this selection (choice) is a hierarchy of their social roles, which are based on identity. Identities for the person have the quality of values, differences regarding these values and define the hierarchy of social roles. The two phenomena - the need and interest - appear .in the interaction with the media world on the basis of identity.

The need for the media, as a rule, is determined by the actuality, real social roles - domestic, professional and consumer-oriented. If necessary, media world appears as a system that requires from the recipient the corresponding relationship to itself as a part of the system performing certain social roles, i.e. media world structures and regulates human relations when a person operates in an orderly and regulatory world. Understanding persons on the basis of social conditions surrounding them, on the basis of their social status and their respective roles, is achieved only in the context of the regulation of behavior and activity, a total of structuring of human relations.

Interest, on the contrary, emerges as a reaction to the media suggestion (which may have nothing in common with the reality of the recipient), either as a purposeful action towards specific (interesting) knowledge and information. In the case of interest emerging to the text the recipient acquires a new social role; the process of its occurrence is called identification ("empathy" according to Bakhtin). From this point of view, we can assume that the main task of journalism in the field of mass communication is to stimulate the identification. Media world allows the recipient to prove himself as an independent ("integral") subject (actor), which, in fact, determines the attractiveness of the media to the individual. In this case, the attitude to the man is changed, he/she appears as the center of his/her own philosophical system of valuable coordinates of worldview that define his/her media behavior. The Internet and the global digitalization of media allow assessing the personality via the network routes and media preferences, which are read and recorded in real time, converting the sociology of media into the statistics. The problem of understanding a person in the media world is removed. Achieving understanding is happening through the information consumed by the person, to which he/she responds, and communication, into which he/she is included, which he/she initiates or triggers. In this context, there appears the problem of responsibility of the recipient for his/her media behavior, which is an incentive for producers of information content.

The next level of the understanding model suggests the occurrence of the recipient's relationship to the assessment contained in the message (the work) text. Without evaluating the text does not exist, the assessment is conditioned by the inevitability of fact selection by a journalist from the sphere of actuality, the inevitability of the editorial policy and the inevitability of the media classification in the mind of a certain individual or the society on the basis of reference to the value, (ideology, style, craftsmanship). The result of the relationship of the recipient and the audience in general is the trust/distrust to this or that mass media. It is necessary to take into account that the recipient has to do with the text, which (according to his/her sensation) absorbs the author, the characters and the recipient himself/herself. The relationship of trust gives rise to the subject-object identity, leading to endowing objects (texts, authors, characters, the mass media) with the valuable sense and the emergence of media identities.

As a result of the act of communication a social action occurs carried out by the recipients. The social action, in turn, becomes a fact (phenomenon of reality), the details of which have a chance to become the property of the media. Further, we observe the cycle described previously. Understanding as the process involves methodical contents; however, the key issue for the beginning of research on this problem is the opinion ("pivot point"), from the standpoint of which the study of the phenomenon is carried out. Such points of view can be described as objectified scientific interest, the position of the editorial board, the national or public interest, party membership, private or personal interest. 


\section{Discussion}

\subsection{Use of the results in the conventional model of effects}

While strengthening the factor of the mass media in public life and increasing the subjective role of the person in mass communications, the universal significance of information and communications leading to social changes is increasingly substantiated in the theories and conceptions.

The transition from the understanding a person to understanding social processes implies an appeal to analysis of the communicative efficiency. The distribution by the scales of "planned - unplanned" and "short-term - long-term" effects is in the basis of the system of mass communication effects. Understanding is present in all kinds of effects emphasized, but depending on them it has different qualities. Motives and orientations of the subjects of communication (communicators, authors, recipients, mediators, organizers) are of importance in the "planned - unplanned" effects. "Short term - long-term" effects suggest consideration of the dynamics of understanding in the system of relations of "the means of mass communication (MMC) - the society, the group (community), the man".

In the most general approximation the effect is recognized as the communication impacts, in social life, as it has been already noted, these are social actions. Correlation with the actions of other people have already suggested both understanding the meaning of these actions, and communication (including the indirect one) between the carriers of such meanings. At the individual level, the social action as a communicative effect manifests itself as a social role - the expected behavior according to the status of the acting individual. Based on the status the identity is formed as a sensation of belonging to a particular group. At the group level the identities demonstrate cumulative effects that result from the various options of communities' communication compatibility or incompatibility. Tolerance, intolerance, xenophobia, conflict and so on may be considered as such options.

Planned short-term effects include individual responses (replies, reactions to the message), which are expressed in changing or preservation of attitudes, and campaigns using several channels of mass communication by which the communicator's objectives are achieved. The effectiveness of individual reactions and campaigns using MMC is achieved in conditions where there is the need for information dependent upon social actuality. Effective appeal to the needs anticipates the presence of communication system requiring from the recipient the corresponding relationship to himself/herself as a part of society fulfilling certain social roles. In this case, mass communication is involved in the structuring and regulation of human relations, it streamlines the regulatory standard of the world. In the system of planned short-term effects both the current state of social relations and the institutional ability of society to communicatively respond to the needs are subject to understanding.

Planned long-term effects are also based on needs, but taking into account the hierarchy of identities. This group of effects is represented by the spread of innovations and distribution of information and knowledge. The efficiency is provided by the distribution of information between social groups, priorities marking in coverage of certain fragments of actuality and reality and the reality acting as separate spheres of understanding.

Unplanned short-term effects manifest themselves both as individual and collective responses to communicative action. To understand the nature of this group of effects it is required to attract such category as interest (as opposed to the need, not determined by social reality).

Unplanned long-term effects include: socialization, social control, "vision" of social reality, institutional and cultural changes, the impact on the results of the events. The fact of actuality change based on the recipient's relationship to the assessment contained in the message text (the work) is of importance in these consequences.

\subsection{New effects}

Social control also acts as a natural regulatory function of journalism. The forms of social control are the formation of public opinion (moreover, in all its manifestations - the dissemination of knowledge through the creation of the competent audience, the development of the social evaluations system and incentive to action) and maintenance of social institutions, including journalism. The methods of social control are isolation, separation and rehabilitation. Isolation (deprivation within the meaning of non-coverage of certain events, phenomena, facts, situations, characters and so on) appears as ignoring, withdrawal of objects from the information space, and therefore the field of public opinion, social debate and discussion. The separation is reproduced in forms of social and political criticism, including media criticism. Rehabilitation is carried out by a constructive discussion of the problems through the adoption of the role of the opponents and understanding of their behavior values and motives.

In the context of change of technological modes when the main resource of development is not information, but the 
man himself, preservation of existing methods and models used to describe understanding in mass communication in a more or less short term seems problematic. The importance of symbolic consumption is intensified, the realization of social status is achieved through it, and reproduction of real infrastructures takes place via the network communication processes. Management, trade, services, entertainment, crime, etc. penetrate into the media environment. A reverse process - mediatization of actuality - occurs. It is exemplified by the projects of public space mediatization via a live video and video monitoring and 3D mapping and so on.

Mediatization of organizations is referred to specific communicative effects. Any public events or organizational campaigns (concerts, presentations, lectures, exhibitions, conferences, workshops and so on) have a chance to become a media event. Besides mediatization becomes an essential feature of the organization in the meaning of its document flow legalization, regulatory structuring of its activities. Organizations are transformed into open, cooperable and interactive media environments - those of the municipal government and self-government, social activity and civilian control, the economy and business, education and science, culture and art, medicine and services, leisure and everyday life, and so on.

Mediatization of private life also acts as a communicative effect. It is based on the postulate of the freedom to demonstrate privacy. The individual is required, at least, to give the agreement that the usual social roles and identities are combined (or even replaced) with the game ones. Accordingly, the value of relational functions is increasing in the media environment legitimizing the game as a type of social behavior in the media space. New ways of communication will demand identical new solutions in the field of social organization, new ethical and regulatory solutions, and new ways of understanding, self-understanding and mutual understanding.

\section{Conclusions}

\subsection{Future research directions}

Journalists rarely read different thoughts in the work in addition to those that are directly related to the events narrated in it. If the recipient (or media critics) sometimes finds a new meaning in the work, it does not mean that there really was no such meaning there. It is there, even when the author did not consciously mean it. Since the actuality itself has the sense of its own, while demonstrating it the author reproduces its meanings.

To understand a man is more complex. To start with, it is necessary to reveal whether the person understands himself/herself as a text, what meanings he puts into it. The answer here can be observation over the process how a person evaluates ("reads") the others. The characterizations are based on the assessment methods "on the part of oneself" "if someone is this, he is this in comparison with me"), "on the part of similar" ("if someone is this, he is this in comparison with the similar") and "on the part of the generalized other" ("if someone is this, then whether it is normal").

The protest of an individual against the actuality has the anthropological nature. Protest (the same as justification) regarding the actual world is caused not only by the collision between the actual and the real, but also by way of estimating a person not just through the text, but also as a text. The very "matrix" character of understanding triggers a protest against the textual reading of a human being.

Methodically the solution of the problem of understanding in the part that relates to the observed and fixed social action implies the analysis of the structure of time and attention. For example, in the analysis of human media behavior it is important to determine what part in the budget of the time is occupied by the media in their meaningful, stylistic and formal dimension. What is the connection between mass information, communication and the needs and interests of a human being? What are the ways the authors, organizers of information and regulators of communication carry on encouraging the identifications? What is the degree of mutual trust/ distrust in the media environment?

Understanding as the goal and the result of journalistic activity is intended to include the explanation and interpretations into the complex of journalistic functions. However, one should take into account the "strength of materials" in the medium of mass communication, i.e. the limited influence of journalism in the process of understanding social actions and human behavior: "No man, however powerful he may be, can remove the established concepts and ideas from people's minds and put the others, invented by himself in their place"(Rozanov, 1996).

\subsection{The study of the author's motivation as a field of research}

A separate line of studying the problem of understanding in journalism and mass communication should be mastering the motivational complex of conditions of the author's success, which should be understood as the essential characteristics of the efficiency of the media. The structure, shape, and the efficiency of the work of journalism in addition to the objective 
factors of the socio-political environment of the media functioning and information production technology depend as well on the author's subjective choice of the grounds for the activity conditions, attitudes towards his/her role behavior at the stage of information gathering and the planned purposes of the work publication.

The grounds for the activity include reflective, normative, pragmatic and emotional conditions.

Reflective conditions consist in understanding by a journalist his/her "mission", the comprehension of that he considers his vocation, mission and, therefore, which professional roles he/she should perform. In this case, no question of professional ethics emerges: one journalist thinks that his/her mission is to criticize the authorities, another one considers that he/she should meet the audience's interest in the private life of political leaders, and the third one believes that his/her mission is the unbiased information, free of his/her own value judgments, etc.

Ethical requirements begin to manifest themselves in the regulatory environment, which also include the legal requirements and permits. Discord of reflective and regulatory components of professional activity leads to the conflicts of grounds. For example, a journalist considering that his/her mission is to criticize the government, is constantly faced with serious regulatory obstacles. Trying to highlight an unsanctioned rally leads to administrative detention, the creation of the material on the construction of suburban villas by the officials involves prosecution for trespassing, environmental investigation ends with a court decision on the disclosure of information constituting a state secret. The essence of this type of conflict is that journalists are aware of the consequences of their activities, but take the risk due to the hierarchy of values inherent in them.

Pragmatic conditions of a journalist's activity consist in his/her carrying out what is necessary, what he/she has to do. At this level, the conflict manifests itself as a contradiction both with reflective and normative working conditions. For example, contemporary mass media can successfully exist only if the requirements of the information market, such as demand among consumers, which, in its turn, is guided by the advertisers, are followed. Journalists in such circumstances are forced to play the role of "media workers", which may not correspond to their ideas about their mission (reflective conditions) and in conflict with the law and professional ethics requirements (regulatory conditions).

Emotional conditions of journalistic work appear as satisfaction, pleasure from work, from its process and results. The conflict at this level appears as a set of contradictions of reflective, regulatory, pragmatic and emotional components of professional activity. The ideal model of the professional activity is such a state in which there are no contradictions revealed when reflectivity (vocation), standard (requirements), pragmatism (the necessity) and emotion (satisfaction) coexist in harmony. While performing a journalistic critical function, social control function in an environment where criticizing authorities is habitual, allowed, necessary, and one likes it, we get the classic type of the journalist - the public defender and educator. But, when the disorder of the revealed conditions appears, there is a conflict, and to criticize the authorities in the media is no longer possible, the journalist takes his/her unspent energy and professional passion where, for example, regulatory and pragmatic conditions no longer apply - to the Internet, blogs. Priority of pragmatism over reflectivity can lead journalists to alienation from the society and emotionality over regulation - to the condemnation by the professional community.

\section{References}

Aristotle. (1976). Metafizika [Metaphysics]. Soch. v 4 tt. T. 1. Moscow: Mysl, p. 280 [in Russian].

Bakhtin, M.M. (2003). Avtor i geroy v esteticheskoy deyatelnosti [The Author and the Character in the Aesthetic Activity ]. Sobr. soch. Vol. 1. Moscow: Russkie slovari, p.106 [in Russian].

Blokhin, I.N. (2012). Grazhdanin mediapolisa [A Citizen of Mediapolis]. Sovremennyiy rossijskiy mediapolis. St. Petersburg: SPbGU, Filologicheskiy f-t, p.p 221-226. [in Russian].

Derrida, J. (2000). O grammatologii [Of Grammatology]. Moscow: Ad Marginem, p.171[in Russian].

Gadamer, H.-G. (1988). Istina i metod: Osnovy filosofskoy germenevtiki [The Truth and the Method. Basics of Philosophical Hermeneutics ]. Moscow: Progress, p.227 [in Russian].

Gofman, I. (2000). Predstavlenie sebya drugim v povsednevnoy zhizni [Imagining Oneself Another Person in Everyday Life]. Moscow: Kanon-Press-C, p. 47 [in Russian].

Hegel, G. (1977). Filosofiya duha [Philosophy of Spirit]. Enciklopediya filosofskih nauk. T. 3. Moscow: Mysl , p. 223 [in Russian].

Hegel, G. (1990). Filosofiya prava [Philosophy of Law]. Moscow: Mysl , pp. 142-143 [in Russian].

Heidegger, M. (1997). Bytie i vremya [Being and Time]. Moscow: Ad Marginem, p.230; 235 [in

Russian].

Kant, I. (1994). Kritika chistogo razuma [The Critique of Pure Reason]. Soch. v 8 tt. T. 3. Moscow: Choro, p. 598 [in Russian].

Kazennov, A.S. (2015). Ponyatie kak sredstvo i cel ponimaniya [A Concept as a Means and Purpose of Understanding]. Vek informacii. Zhurnalistika XXI veka: kultura ponimaniya. \# 2 (S2). St. Petersburg: SPbGU, VSZhMC, p. 82 [in Russian].

Lich, E. (2001). Kultura i kommunikaciya: Logika vzaimosvyazi simvolov. K ispolzovaniyu strukturnogo analiza v socialnoy antropologii [Culture and Communication. Logics of Symbols Connection]. Moscow: Vostochnaya Literatura RAN [in Russian]. 
Mid, G. (1994). Az i Ya [Elementaries]. Amerikanskaya sociologicheskaya mysl: teksty. Moscow: MGU pp. 227-237 [in Russian].

Noelle-Neumann, E. (1996). Obshhestvennoe mnenie. Otkrytie spirali molchaniya [Public Opinion. Spiral of Silence Discovery]. Moscow: Progress-Akademiya, p. 34 [in Russian].

Piz, A. (2006). Yazyk telodvizheniy [Body Language]. Moscow: Eksmo [in Russian].

Prokhanov, A.A. (2015). Istinnyj ariec [The Genuine Aryan]. Zavtra. 2015.02.04. \# 13, p. 5 [in Russian].

Rozanov, V.V. (1996). O ponimanii: Opyt issledovaniya prirody, granic i vnutrennego stroeniya nauki kak celnogo znaniya [On Understanding. Research Experience of Nature, Borders and the Inner Structure of Science as Integral Knowledge]. Moscow: Tanais , p. 558 [in Russian].

Rose, A. (2015). Katastrofy moglo i ne byt. Bolnaya psixika vtorogo pilota unesla 150 chelovecheskih zhizney [The Crash may have not Occurred. 150 Human Lives Lost because of Psychologically Unstable Copilot]. Rossiyskaya gazeta. 2015.30.03. [in Russian].

Salynskiy, D.A. (2009). Kinogermenevtika Tarkovskogo [Tarkovsky's Cinema Hermeneutics]. Moscow: Kvadriga, p. 41 [in Russian].

Sarabyan, E. (2011). Akterskiy trening po sisteme Stanislavskogo. Intellekt. Voobrazhenie. Emocii. Metod deystvennogo razvitiya [Actors' training according to Stanilslavsky's System]. Moscow: AST, p. 8 [in Russian].

Shmonin, D.V. (2012). Sholasticheskiy racionalizm v istorii myshleniya: ot Srednih vekov k Novomu vremeni [Scholastic Rationalism in the History of Thinking: from the Middle Ages to the New Time ]. St. Petersburg: RHGA, pp. 63-64 [in Russian].

Torsueva, I.G. (1976). Emocionalnost v rechi [Emocionality in Speech]. Smyslovoe vospriyatie rechevogo soobshheniya (v usloviyax massovoy kommunikacii). Moscow: Nauka [in Russian].

Veber, M. (1990). Osnovnye sociologicheskie ponyatiya [Basic Sociological Concepts]. Izbrannye proizvedeniya. Moscow: Progress, p. 603 [in Russian].

Wittgenshtein, L. (1994). O dostovernosti [On Authenticity]. Filosofskie raboty. Ch. 1. Moscow: Gnozis, p. 330 [in Russian].

Zinovyev, A.A. (2006). Faktor ponimaniya [Factor of Ubderstanding]. Moscow: Algoritm, Eksmo, p.7 [in Russian]. 